\title{
Search for Harmony of Freedom and Justice in the Republic of Kazakhstan
}

\section{Gizatullina GA*}

Department of Philology, Taraz state University, Republic of Kazakhstan

*Corresponding author: Gulgina Alimzhanovna Gizatullina, Associate Professor, Candidate of Philology, Taraz state University, Taraz city, Republic of Kazakhstan,Email: dafna_89@mail.

\section{Investigation Paper}

Volume 3 Issue 4

Received Date: September 21, 2020

Published Date: October 06, 2020

DOI: $10.23880 / a b c a-16000138$

\section{Abstract}

The article poses the problem of harmonization of freedom and justice in modern socially-oriented states. The author carries out a theoretical analysis of the relationship between freedom and justice and concludes that, despite the difference between the two concepts, they are interconnected and interdependent and, therefore, compatible. Justice is present at the level of economic freedom and is manifested in the equal labor market and in the fair distribution of state property. In politics, freedom and justice can coexist harmoniously in a narrower space at the level of general democratic demands. The author notes that this process is complicated by globalization. The countries-subjects of globalization pursue a policy of unhindered movement of capital around the world and a decrease in the social functions of the state. In these conditions, the states-objects of globalization must resist such a policy and maintain and increase their social functions. For example, the President of Kazakhstan, Kassym-Zhomart Tokayev, has proclaimed the policy of a "hearing" state "and the economy of" simple things "that allow avoiding globalization risks. The author concludes that all countries of the post-Soviet space should resist globalization by all-round development, improvement of social functions of the state, achieving social justice. It is the implementation of the concept of the President of Kazakhstan "Hearing State" that will harmonize freedom and justice. If capitalism gives freedom, and socialism gives justice, then modern states have a historical chance to find harmony of freedom and justice.

Keywords: Freedom; Liberalism; Justice; Subjects and Objects of Globalization; Hearing State; Globalization; Inequality; Socially-Oriented State; Inequality

\section{Introduction}

The article deals with the problem of harmonizing freedom and justice in modern socially oriented States. The author conducts a theoretical analysis of the relationship between freedom and justice and concludes that, despite the difference between these two concepts, they are interrelated and interdependent and, therefore, compatible. Justice is present at the level of economic freedom and manifests itself in an equal labor market and in a fair distribution of state property. In politics, freedom and justice can coexist harmoniously in a narrower space at the level of common democratic requirements. The author notes that this process is complicated by globalization. Globalizing countries pursue a policy of unrestricted movement of capital around the world and reducing the social functions of the state. In these circumstances, the target States of globalization need to resist such policies and preserve and multiply their social functions. For example, the President of Kazakhstan KassymZhomart Tokayev proclaimed the policy of a "hearing "state" and the economy of "simple things" that allow avoiding the risks of globalization. The author concludes that all countries of the post-Soviet space should resist globalization with all possible development, improvement of social functions of the 
state, achieving social justice. It is the implementation of the concept of the President of Kazakhstan "Hearing state" that will allow to harmonize freedom and justice. If capitalism gives freedom, and socialism gives justice, then modern States have a historical chanceto find a harmony of freedom and justice. Keywords: freedom, liberalism, justice, subjects and objects of globalization, a hearing state, globalization, inequality, a socially oriented state. Since the time of Plato and Aristotle, there has been a dispute about whether freedom or justice should prevail in the state. In politics and philosophy, the concepts of "freedom" and" justice" are most often opposed to each other. The concept of "freedom" in modern political science is usually associated with the ideology of liberalism. The very term "liberalism", "liberal" is derived from the Latin libertas, i.e. "freedom". The philosophy of liberalism sees a person as absolutely free, best adapted to the surrounding conditions. Following reasonable egoism, he achieves his goals in any way, enjoys life, and lives for his own pleasure. This might seem cynical and immoral, but liberals argue that if each member of society is free and acts only on the basis of their own selfish interests, gets rich and seeks personal success, then the whole society as a whole will sooner or later begin to flourish, because it consists of individual units who are happy individually. Apologists of freedom praise the spirit of entrepreneurship, which leads to the development of public institutions, and the element of the market leads to the satisfaction of all needs, because it is flexible in responding to the dynamics of people's desires. Freedom is necessary for strong individuals; it opens up distant horizons for them. But weak people who are not able to rise up on their own strength alone, leads to poverty and a miserable existence. Freedom can lead to wealth and poverty, to greatness and misery, to victory and defeat. But in any case, all the claims a person makes only to himself: in liberal philosophy, no one owes anyone anything. Those countries that have achieved maximum economic and technical development have really come to this, moving along the path of liberalism, professing the principle of "freedom above all else" [1]. The concept of justice is interpreted differently, because it is associated with the archetypes of popular thinking, which are reproduced time after time, even when changing ideologies. In the Western sense, justice is law. What is legal is fair. But if we turn to Russian philosophical literature (the end of XI century) "the sermon on law and grace" Metropolitan Hilarion, the treatise States that grace is above the law: "the law was the forerunner and servant of grace and truth, truth and grace servant of the next century, life imperishable". Thus, Hilarion sees in the law justification, and in grace salvation. This means that "grace" is the highest justice, divine. And it is above any law [2]. This understanding of "justice" is typical for all Eurasian peoples and during the years of Soviet power, all the peoples of the Soviet Union perceived justice in this way and following the "rule of law", we must realize that this law must be based on our historical understanding of justice. Otherwise, this law will not work, be respected and observed. In addition, you can see the unity of freedom and justice in the economy. As m writes about it: Leontief it is clear that there is a concept of "market fairness" within the market, which is also related to efficiency: it is equal opportunities for players. And ensuring these equal opportunities is a routine work of the state (competition protection, antitrust legislation, business climate, guarantees of property relations, etc.) [2]. However, in politics, these concepts do not agree, because the concept of "social justice" lies outside of market relations. This is reflected in the classic alternative: liberal economic freedom is manifested in the fact that the unsuccessful should not parasitize at the expense of successful people and "the rich should not share". In our archetype they should share their wealth [2]. the Absolute value for the Eurasian society and state is the rejection of social Darwinism. We mean equal access to education and healthcare, not only in the context of "equal opportunities", but also in terms of our civilizational requirements and the goals of the state in relation to its citizens. If we talk about the state's participation in redistribution, we should bear in mind not only social guarantees, pension guarantees, and provision for socially vulnerable strata we are also talking about solving the problem of poverty, which we "earned" 30 years ago. The measure of disease is the so-called decile coefficient, the income gap between rich and poor, which has reached astronomical figures in our country. We can name two main factors that reproduce this problem and thus exacerbate social inequality.

- The erosion of the "middle class".

- The slowdown in the development of the labor market, the depreciation of the labor force.

Both are the natural result of the" wild capitalism" that we formed in the 90s and which has not yet been overcome [2]. Many see a possible solution to this problem in the redistribution of wealth. I propose to introduce a progressive tax: the idea is not absurd, but in our current circumstances was unjustified, because inevitably fall tax collection or this act will only lead to the withdrawal of income from tax in different ways. A more thoughtful solution to this problem is the "luxury tax". Moreover, such a decision is more consistent with the causes of socio-psychological, rather than fiscal fiscal value, it is just small. We must reduce conspicuous overuse, which is not approved by any tradition or culture among the Nouveau riche; it is, in fact, a "tax of justice". This tax should be introduced not so much for economic reasons as for ethical reasons [2]. Fairness also requires overcoming the high concentration of capital, compounded by corrupt and bureaucratic encumbrances on business, and corruption of the labor market. This market is an ugly product of economic lawlessness employers'.

The actual sellers of labor do not play an equal role in 
this market $[2,3]$. The labor market can be effective when the buyer and seller are in equal competitive conditions and for this, we need strong, working trade unions this is a necessary element of a normal labor market. The idea of full equality is ineffective, as was proved in the era of socialism, but it is also unfair. In order to recognize the fairness of redistribution, we must recognize the injustice of equalization. The Communists decided this issue through the prism of a complete future of Communist abundance, which unfortunately, they could not achieve. The justice of inequality can be recognized if the reasons for this inequality, its economic nature, are sufficiently honest and legitimate. Inequality cannot be based on theft and corruption. It is impossible to convince our people of the justice and legitimacy of inequality based on unfair play. In addition, inequality in our country is based on the illegitimacy of existing property relations. We are referring to the distribution of the best pieces of state property outside of the General standard procedures even for that time. Suffice it to recall that the "big privatization" was clearly unfair. No one will dispute the fact that colossal assets were actually given to a narrow group of individuals for free $[2,4]$. If the state tries to legitimize unjustly acquired property by its own will, it will delegitimize itself and, most importantly, this problem is not only facing society and the state it is facing the owners themselves. And they know exactly how precarious the grounds for owning their current assets are. And this understanding is reflected in their "offshore" behavior not only economic, but also political. It would be fair to offer them a kind of concordat-a voluntary agreement and first of all, not with the state, but with society. Evaluate the current" fair value" of the property received for free or for nothing, offers to buy back return the difference to the country. Naturally, it is formed into some kind of debt obligations, stretched over 10-15 years [2]. No one talks about theft, but about acquisition in the conditions of extremely imperfect and unfair legislation and paralysis of the state. Modern oligarchs cannot be called criminals, but rather they are people who have taken advantage of circumstances adroitly. This is a draft of a new social contract that, if it is legitimately approved by the people, will legitimize the entire existing property system and citizens will consider this model acceptable and fair [2]. Only on this basis can a system be built in which property is truly sacred and inviolable. The legitimate structure of the state, legitimate power is based on law. But not to a formal right, but to the right recognized by the people to govern it. Democracy begins with justice in this case, the state acts as the highest authority to protect its citizens from injustice. Justice requires coherence between government and society, and it is a collective concept. Societies that focus on justice give citizens a greater sense of confidence, security, and peace of mind. Here the weak, ill, and awkward know that they have protection and protection. But at the same time, such a philosophy constrains the development of entrepreneurial spirit, restricts private initiative, and deprives strong individuals of the incentive to personal advancement because the results will still be shared by all. There are two opposing value systems. Two types of society. Two models of the state. But all modern States strive to harmonize these two opposite principles and the theoretical analysis has shown that it is possible to reconcile these two concepts in both Economics and politics. Only for this purpose, the state must restore order in the labor market, introduce equal conditions for market traders, introduce a luxury tax and conclude an agreement with those owners who once bought up state property for a song. Then we can talk about a socially oriented state, where the harmony of freedom and justice is realized. Although such a philosopher and political scientist as Jurgen Habermas believe that the modern state cannot implement the principle of justice. This is hindered by globalization, which takes place under the banner of liberalism and reduces the social functions of the state. In the post-Soviet space, all the former republics of the Soviet Union have experienced all the charms of liberal ideology. The ideologists of liberalism, at the critical moment when the transition from the planned Soviet economy to the free market was taking place, promised everyone that the market would put everything in its place and indeed, the market put everything in its place, but only in an anti-social sense, when the bulk of the population became impoverished, bankrupt and became a hostage of the huge, all-powerful banking system and a small group of billionaires has become enormously rich.

If in 1960 the difference in income between the richest fifth of the population and the poorest fifth of the population in the world was 30:1, then in 1997 it was 74:1 [5]. All the republics of the former USSR were involved in globalization. Moreover, all these republics, now independent States, became objects of globalization, which the subjects of globalization imposed a policy of liberalism with the freedom of movement of capital, minimizing capital taxation and refusing social benefits. In these circumstances, the role of the state has been significantly reduced. Globalization has consistently led to the degeneration of all nation-States. There was a crisis of statehood and ethno-national identity. In addition, the striking difference between the wealth of some countries and the extreme poverty of other countries has led to mass migration, an outflow of population from underdeveloped countries to rich fast-developing countries. By 2015, the migration rate was 248 million people [6]. What has mass migration led to? To reduce the economic and demographic potential of underdeveloped countries and increase tension and deviance in Western European countries, another Vice of globalization is the unification of culture, the formation of a single universal culture, which calls into question the existence of national cultures. It should be noted that it is not globalization itself that is dangerous, it is an objective process, but in what form it is carried out by 
the subjects of globalization, the United States and Western Europe. It is enough to recall the surprisingly accurate description of globalization in the Communist Manifesto: "instead of the old local and national isolation and existence at the expense of the products of their own production, there is an all-round connection and all-round dependence of Nations on each other. This applies equally to both material and spiritual production [7]. Countries that are subjects of globalization deliberately and thoughtfully use globalization for their own enrichment and open plunder of other peoples, whom they have made objects of modernization. However, we should not stop at the actions of individuals and institutions; a truly scientific approach requires going deeper studying the objective foundations of globalization, which sweeps away any national, cultural and territorial restrictions in its path, if they prevent the growth of profits. And in this sense, Americanization is only a temporary form, a shell that is convenient for world capital in this historical period, just as capitalism itself is only a temporary historical form for the productive forces United on a global scale by the internal logic of historical development. Globalization cannot be reduced to Americanization, and does not end with capitalism. It is necessary to fight not against globalization, but for a different globalization one that reveals its humanistic content, which opens the prospect of realizing the generic essence of man, i.e. in the development of the ability to creative and creative work [7]. This was repeatedly warned by the First President of Kazakhstan Nazarbaev NA and the current President Kassym-Zhomart Tokayev, who in the first lines of his Address to the people of Kazakhstan noted that the neoliberal model of economy and politics has exhausted itself. Kazakhstan has passed a difficult maturity test, an exam for independence, because the change of power, the transit of power-this is always a very difficult process. It is enough to point to the nearest neighbors of Kazakhstan: Uzbekistan, Kyrgyzstan, Tajikistan, and Turkmenistan. Political scientists note that in the process of power transit, it is very important to determine how the change of power is carried out: "a change of regime or just a change of face." For example, in Tajikistan and Turkmenistan, there was a change of face, but not a change of regime. Uzbekistan has seen both a change of face and a change of regime. In Kyrgyzstan, both the person and the regime are constantly changing, but there the process of power change always occurs in a conflict form, which is completely unacceptable for Kazakhstan. Political scientists have developed three possible scenarios for Kazakhstan [8].

- The first scenario is called "winner takes all". If you imagine that a certain force comes to power illegally and seizes everything that comes to hand. The country begins a civil war and to stabilize the situation, some external force breaks into the country and establishes its own puppet regime. Then they hold a demonstration election, put their man in power and control this state.

- The second scenario assumes that a person from his own circle comes to power, who does not change anything in the existing regime.

- The third scenario provides for legitimate elections and the coming to power of a new person who gradually changes the existing regime without confrontation and today we can say that the third scenario of power transit has been implemented in the Republic.

This process was painless, legal, and open 9 candidates participated in the elections, including one woman. Legally won Kassym-Zhomart Tokayev from the very first steps of becoming President, he began to talk about the continuity of the course of Nazarbayev NA, building a socially-oriented state to create a society of abundance and Universal labor. At the same time, his further steps have shown that he wants to continue to reform the political system, something that N. Putin has repeatedly said. Nazarbayev believes that Kazakhstan should move from an authoritarian democracy to a parliamentary Republic. And already in his Message to the people, Tokayev spoke of the need to create a "Hearing state". This means that officials must listen to their people, their aspirations and needs. This issue is very relevant, as sociologists and political scientists note a communication crisis in Kazakhstan. According to experts, the typical features of the communication crisis between society and the government are: a crisis of trust (38.1\%), a delayed response to requests and demands of society from the authorities (18.6\%), the absence of a "feedback loop" (15.0\%), a different interpretation of events (14.2\%), distorted statistics (9.7\%) [8]. Tokayev also fights against the erosion of the middle class, as the Message was about doubling the salary of teachers. In addition, he himself issued a decree on reducing the credit burden for the most vulnerable segments of the population. 276 million tenge was allocated for this purpose. 500,000 people were released from credit debts [9]. He also noted in his Message that officials need to learn not only to hear their people, but also to be able to conduct a dialogue with them, so that people do not take to the streets with their demands as a sign of protest. "We don't need street democracy," the President said. It is enough to recall the events of December 16,1986 , when the authorities failed to hear their people and youth, which led to numerous victims [10]. Then, Tokayev called for improving the work of the Parliament of the Republic and drew attention to the fact that the parliamentary elections should be open. After all, all political parties in Kazakhstan must pass the school of hard competition, so that there is no "undercover fight of bulldogs", and there is a transparent public competition between different programs of political parties. The Parliament should be authoritative and influential. The President himself derived the modern power formula "a strong President an influential Parliamentan Executive government [10]". The formation of a "hearing 
state" requires the development of civil society. Tokayev not only spoke about the need to form an active civic position among citizens of Kazakhstan, but also about a scientific approach to this issue. Therefore, he gave instructions to create a concept of civil society, justifying the role of nongovernmental organizations [10].

Kazakh politicians note that political power should be socially responsible, and that it is impossible without effective control from the society. The nature of political power is such that it creates a "temptation" to use it for personal and narrow-group interests. That is why the new steps taken in Kazakhstan to combat corruption are so relevant. In regions, the prevention and fight against corruption organized in the project "Shygys-daldy Alay". In the direction of "eliminating domestic corruption and creating comfortable conditions for citizens", work on digitalization is being carried out on a systematic basis cifrovization various spheres, which allows minimizing corruption risks. Through the center for electronic services and the "E -akimat" system, the business processes of government agencies have been automated. As a result, the average time frame for providing public services has been reduced by 3.5times and the transparency of their receipt has been ensured [9]. The Leaders of the Nur Otan party propose constructive cooperation with public organizations and political parties to strengthen social harmony and develop civil society. In this regard, they set a task for their party to become the main dialogue platform, taking control of the consideration of all complaints and applications received from various sources, using the tools of "feedback": party hearings and new methods of working with digital technologies [9]". In his address, the President spoke about the need to prevent the risks of globalization. Kazakhstan once suffered from Soviet Imperial dependence. Although it should be noted that despite the fact that the Center took a lot from the republics, it also gave a lot away over the years of Independence, Kazakhstan has become an independent state, but today there is a new threat-dependence on the IMF, on international banks, and transnational corporations. Moreover, international funds only take away and do not give anything away. We must not forget the predatory nature of capitalism, as Marx constantly warned us and if modern capitalism has loosened its predatory grin a little, it has done so thanks to Soviet socialism. It was the system of socialism in the USSR that made modern Western capitalism civilized. We should not forget that. To counteract the risks of globalization, as the President wrote about it, we need to develop the national industry, we need to develop the agricultural sector, and for this to improve life in villages, we need to create an economy of "simple things", that is, support those small and medium-sized businesses that will create basic necessities [10]. Today, all countries of the post-Soviet space must resist globalization with all possible development, improving the social functions of the state, which will be able to achieve harmony, freedom and justice. It is the concept of the President of Kazakhstan of a "Hearing state" that will allow us to introduce freedom and responsibility, as well as justice and freedom. However, much more needs to be done to create a truly socially oriented state.

\section{References}

1. Vasilik MA Politologiya-file $\mathrm{n} 1 \mathrm{doc}, \mathrm{pp}: 2-10$.

2. Leontiev M However 18/167. nASHI values.

3. Bagramov EA (2010) National problems: in search of new conceptual approaches. Question of philosophy 2: 34-52.

4. Dumesnil J, Levi D (2005) The nature and contradictions of neoliberalism. Prognosis, pp: 61-84.

5. Knocked A (2000) Globalization of the world economy. International life 5: 49-56.

6. Simonyan RH (2018) the Crisis of the liberal-market model of globalization. Question of philosophy.

7. Musaelyan LA (2016) Historical process and globalization. Yale University 128: 6.

8. Satpayev D (2020) vertical Deformation. From anonymous empires to anti-lobbyists. "Black folder" of communication and political upgrade in Kazakhstan in the conditions of transit of power".

9. Mukhtarkhanova (2019) Conception of the "hearing state" of Letters.

10. Tokayev KT (2019) Message of people of Kazakhstan. IaNews.

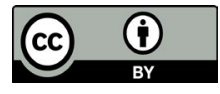

